\title{
RANCANG BANGUN SISTEM PELAPORAN ANGGARAN DANA BANTUAN OPERASIONAL SEKOLAH (BOS) BERBASIS WEB DI DINAS PENDIDIKAN KABUPATEN JOMBANG
}

\author{
Ahmad Heru Mujianto \\ Universitas Pesantren Tinggi Darul Ulum Jombang \\ ahmadheru13@gmail.com
}

\begin{abstract}
Abstrak
Mulai beberapa tahun yang lalu, pemerintah menggulirkan dana subsidi pendidikan bagi sekolah-sekolah yang disebut bantuan operasional sekolah (BOS). Dalam pelaksanaannya, BOS diberikan dan dikelola oleh setiap sekolah dengan diawasi oleh berbagai pihak, baik instansi resmi maupun komite sekolah. Untuk itu perlu dibuat sistem yang mampu mengelola dana BOS. Sistem ini dibangun menggunakan Framework Codeigniter dengan model pengembangan MVC (Model View Controller) dan basis data MySQL. Framework Codeigniter digunakan karena dengan menggunakan framework ini dapat langsung fokus kepada business process yang dihadapi tanpa harus berfikir banyak masalah struktur aplikasi. Sistem Pelaporan yang dibangun ini mampu membuat form Dokumentasi Kegiatan dan Anggaran Sekolah (DKAS), melakukan pencatatan transaksi dana BOS dan juga membuat pelaporan realisasi penggunaan dana BOS. Sistem ini mampu membantu kinerja sekolah dalam pembuatan laporan dana BOS, dan membantu pihak Dinas Pendidikan dalam melihat pengelolaan dana BOS masing-masing sekolah, hal ini akan lebih efektif dan efesien dalam pelaporannya.
\end{abstract}

Kata Kunci : Dana BOS, Pelaporan, Web, Framework Codeigniter, PHP.

\begin{abstract}
Abstrack
Start of some years ago, the government education subsidy distributing the fund for schools that called school operational assistance (in Indonesian language called, "BOS = Bantuan Operasional Sekolah"). In its implementation, BOS given and managed by each school with supervised for various parties good official agencies and school committees. For that system will need to be made which is able to manage BOS funds. The system was built using Framework Codeigniter with model of MVC (models view controller) and MySQL database. Framework Codeigniter used, because using this framework could be directly focused on business process faced by without having to think a lot of problems the structure of application. The reporting system that was built was able to make form documentation activities and school spending (in Indonesian language called, "DKAS = Dokumentasi Kegiatan dan Anggaran Sekolah"), do the registration of transactions BOS funds and also makes reporting realization use BOS. This system able to help the performance of school in the manufacture of reports BOS, and help the local education office within view the management of funds BOS each school, it will be more effective and efficient in the reporting.

Keyword : BOS Funds, Reporting, Web, Framework Codeingniter, PHP.
\end{abstract}




\section{Pendahuluan}

Mulai beberapa tahun yang lalu, secara periodik pemerintah menggulirkan dana subsidi pendidikan bagi sekolahsekolah yang disebut Bantuan Operasional Sekolah (BOS). Pelaksanaan dana BOS diberikan dan dikelola oleh setiap sekolah dengan diawasi oleh berbagai pihak. Para pelaksana program, khususnya di tingkat sekolah, menjadi sangat berhati-hati dan berusaha untuk mematuhi aturan-aturan program, terutama guru banyak yang kerepotan untuk memenuhi tuntutan bentuk standar format laporan. Akan menjadi lebih efektif dan sangat membantu jika teknologi informasi, khususnya teknologi internet diterapkan dalam sistem pembuatan laporan pengelolaan Bantuan Operasional Sekolah (BOS).

Sistem yang dibangun adalah sistem informasi yang berbasis web, dengan menggunakan Framework Codeigniter dan MySQL sebagai penyimpanan datanya. Framework Codeigniter dipilih karena jika dibandingkan dengan Framework yang lain seperti Yii dan CakePHP, Codeigniter mudah dipahami struktur pembuatannya karena framework ini menerapkan pengembangan MVC (Model View Controller) sehingga struktur code menjadi lebih terstruktur dan memiliki standart yang jelas. Selain itu dalam perkembangannya Codeigniter juga memiliki komunitas yang lebih banyak sehingga akan lebih memudahkan kita untuk mengembangkannya.

Sistem yang dalam pengembangan selanjutnya ini berbasis web, dengan maksud bisa di-upload ke internet, hal tersebut diharapkan mampu membantu kinerja sekolah dalam pembuatan pelaporan dana BOS, selain itu memudahkan pihak dinas dalam mengawasi penggunaan dana BOS tiaptiap sekolah, oleh karena hasil laporan pada masing-masing sekolah bisa dilihat secara langsung. Hal ini akan lebih efisien dibandingkan dengan harus datang langsung untuk memberikan hasil laporan.

\section{Pengertian Dana Bantuan Operasional Sekolah (BOS)}

Menurut Peraturan Mendiknas nomor 69 Tahun 2009, standar biaya operasi nonpersonalia adalah standar biaya yang diperlukan untuk membiayai kegiatan operasi nonpersonalia selama 1 (satu) tahun sebagai bagian dari keseluruhan dana pendidikan agar satuan pendidikan dapat melakukan kegiatan pendidikan secara teratur dan berkelanjutan sesuai Standar Nasional Pendidikan. BOS adalah program pemerintah yang pada dasarnya adalah untuk penyediaan pendanaan biaya operasi nonpersonalia bagi satuan pendidikan dasar sebagai pelaksana program wajib belajar. Namun demikian, ada beberapa jenis pembiayaan investasi dan personalia yang diperbolehkan dibiayai dengan dana BOS (Kemdikbud, 2012).

\section{Metode Penelitian}

Secara ringkas metode dapat diartikan sebagai cara, tahapan-tahapan kegiatan yang akan dilakukan dalam memecahkan masalah yang akan diteliti. Dalam kasus pembuatan skripsi ini metode adalah cara yang digunakan untuk 
mencapai tujuan yang dirumuskan. Metode penelitian yang digunakan sebagai berikut:

\section{1) Metode Pengumpulan Data}

a. Observasi

Yaitu menganalisa kebutuhan data yang akan digunakan untuk membangun website pelaporan dana anggaran bantuan operasional sekolah.

b. Wawancara

Yaitu pertanyaan-pertanyaan yang diajukan kepada pihak-pihak terkait, dalam hal ini kepada salah seorang guru di SDN Karanglo Mojowarno Jombang yang bertugas dalam pembuatan laporan dana BOS, tentang cara pembuatan laporan dan format laporan yang digunakan.

c. Studi Kepustakaan

Yaitu mempelajari dan menelaah beberapa literature yang terkait dengan judul atau masalah yang dibahas dalam rangka memperoleh bahan yang dapat digunakan sebagai landasan teori.

\section{2) Metode Perancangan Perangkat Lunak}

a. UML : adalah metode perancangan perangkat lunak yang berbasis berorientasi objek yang didalamnya terdapat beberapa bentuk seperti Activity Diagram, Usecase Diagram, Sequence Diagram, Class Diagram, dan diagram lainya.

b. Sistem yang akan dibangun ini menggunakan framework Codeigniter dengan metode pengembangan MVC (Model

View Controller).

Codeigniter adalah sebuah framework untuk pengembangan aplikasi website menggunakan PHP. Dengan menggunakan Codeigniter, kita dapat melakukan pengembangan situs dengan lebih cepat daripada membuat nya dari awal karena Codeigniter memiliki banyak library yang memudahkan kita untuk membuat berbagai macam fungsi. Selain itu, Codeigniter juga memudahkan kita dari segi coding termasuk mengurangi banyaknya code yang harus kita pikirkan dalam membuat website (Sidik, 2012).

Codeigniter dibuat dengan menggunakan model MVC sehingga meminimalkan coding yang harus kita buat. Berikut penjelasan yang dimaksud dengan MVC (Sidik, 2012) :

- Model, merepresentasikan struktur data dari aplikasi kita. Pada intinya, di model ini memiliki banyak fungsi yang terfokus untuk melakukan retrieve, insert, update, dan delete record dari database.

$>$ View, adalah bagian yang diperlihatkan pada user. Jadi, halaman web yang ditampilkan di browser adalah code yang kita tuliskan di bagian view. Sebuah view dapat berupa file penuh, atau hanya potongan seperti header atau footer.

Controller, bertugas untuk menjembatani antara model dan view. Selain itu controller juga 
bertugas untuk mengambil library yang ada pada Codeigniter.

\section{3) Diagram Alir Penelitian}

Diagram alir penelitian adalah diagram yang menggambarkan langkahlangkah dalam penelitian yang dilakukan untuk menyelesaikan permasalahan dalam pembuatan sistem. Berikut diagram alir penelitian yang ditunjukkan Gambar 1 .

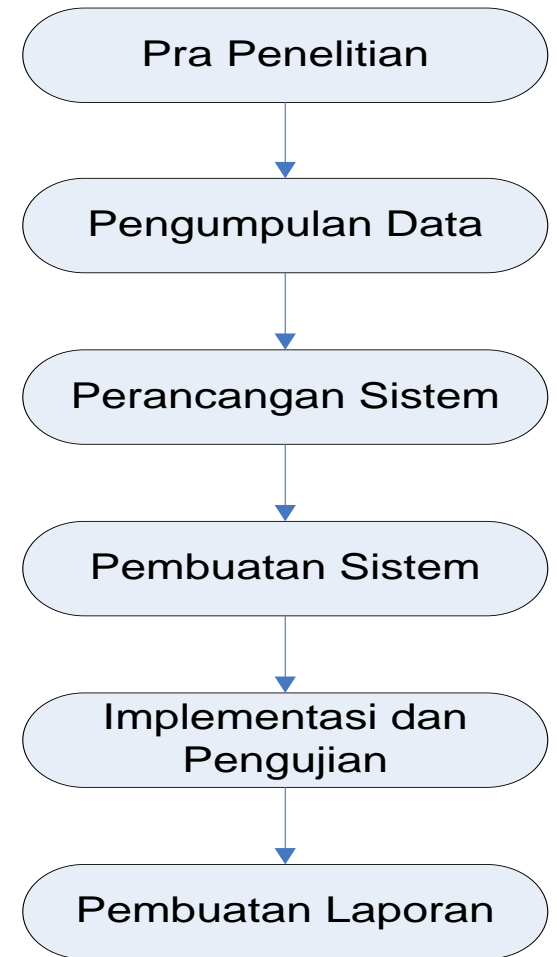

Gambar 1. Diagram Alir Penelitian

\section{Hasil Penelitian Dan Pembahasan}

1) Kebutuhan Input

Kebutuhan input merupakan kebutuhan apa saja yang dibutuhkan untuk data inputan sistem. Berikut kebutuhan input perancangan sistem pelaporan dana BOS seperti yang terlihat pada Tabel 1.

Tabel 1. Kebutuhan Input

\begin{tabular}{|l|c|}
\hline \multicolumn{1}{|c|}{ Input } & Keterangan \\
\hline Data & Data Siswa merupakan data \\
\hline
\end{tabular}

\begin{tabular}{|l|l|}
\hline Siswa & $\begin{array}{l}\text { yang akan dimasukkan dalam } \\
\text { pembuatan DKAS, sehingga } \\
\text { data BOS yang keluar sesuai } \\
\text { dengan jumlah siswa. }\end{array}$ \\
\hline $\begin{array}{l}\text { Data } \\
\text { Rencana } \\
\text { Belanja }\end{array}$ & $\begin{array}{l}\text { Berisi tentang rincian belanja } \\
\text { dan kebutuhan yang akan } \\
\text { dilakukan sekolah selama } \\
\text { satu tahun ke depan. }\end{array}$ \\
\hline $\begin{array}{l}\text { Dana } \\
\text { Anggara } \\
\text { n BOS }\end{array}$ & $\begin{array}{l}\text { Dana ini yang nantinya akan } \\
\text { di terima sekolah sesuai } \\
\text { dengan pengajuan DKAS. }\end{array}$ \\
\hline
\end{tabular}

2) Kebutuhan Proses

Kebutuhan proses merupakan yang dibutuhkan untuk proses yang terdapat pada sistem. Berikut kebutuhan proses perancangan sistem pelaporan BOS seperti yang terlihat pada Tabel 2 .

Tabel 2. Kebutuhan Proses

\begin{tabular}{|c|c|}
\hline Inp & Kete \\
\hline $\begin{array}{l}\text { Proses } \\
\text { pembuatan } \\
\text { DKAS }\end{array}$ & $\begin{array}{l}\text { Pembuatan } \\
\text { merupakan syarat dalam } \\
\text { pengajuan dana BOS. } \\
\text { DKAS berisi tentang } \\
\text { rincian belanja sekolah } \\
\text { (pengeluaran) selama satu } \\
\text { tahun ke depan. }\end{array}$ \\
\hline $\begin{array}{l}\text { Proses } \\
\text { pembuatan } \\
\text { Buku Kas } \\
\text { Umum }\end{array}$ & $\begin{array}{l}\text { Pembuatan Buku Kas } \\
\text { Umum ini digunakan untuk } \\
\text { mencatat transaksi realisasi } \\
\text { dana BOS (penerimaan dan } \\
\text { pengeluaran) }\end{array}$ \\
\hline $\begin{array}{l}\text { Proses } \\
\text { Pembuata } \\
\text { n Laporan } \\
\text { Realisasi } \\
\text { dana BOS }\end{array}$ & $\begin{array}{l}\text { Laporan dana } \text { BOS dibuat } \\
\text { berdasarkan Buku Kas } \\
\text { Umum, laporan ini } \\
\text { menampilkan realisasi dana } \\
\text { BOS. }\end{array}$ \\
\hline
\end{tabular}

\section{3) Kebutuhan Ouput}


Kebutuhan output merupakan kebutuhan yang nantinya menjadi output dari sistem. Berikut kebutuhan output sistem pelaporan dana BOS seperti yang terlihat pada Tabel 3 .

Tabel 3. Kebutuhan Output

\begin{tabular}{|l|l|}
\hline \multicolumn{1}{|c|}{ Input } & \multicolumn{2}{|c|}{ Keterangan } \\
\hline Laporan & Berisi laporan Dokumentasi \\
DKAS & $\begin{array}{l}\text { Kegiatan dan Anggaran } \\
\text { sekolah selama satu tahun } \\
\text { kedepan. }\end{array}$ \\
\hline $\begin{array}{l}\text { Laporan } \\
\text { BKU }\end{array}$ & $\begin{array}{l}\text { Uerisi laporan Buku Kas } \\
\text { UOS. dari transaksi dana }\end{array}$ \\
\hline $\begin{array}{l}\text { Laporan } \\
\text { Realisasi } \\
\text { Dana } \\
\text { BOS }\end{array}$ & Berisi laporan realisasi \\
anggaran dana BOS selama
\end{tabular}

\section{4) Use Case Diagram}

Use case menangkap perilaku yang dibutuhkan dan dikehendaki dari suatu sistem (subsistem, kelas, atau antarmuka) yang akan dikembangkan tanpa menspesifikasikan bagaimana perilaku itu akan diimplementasikan. Dalam kasus ini, pada dasarnya use case merupakan interaksi khusus antara para aktor dan sistem untuk menangkap sasaran serta kebutuhan para aktor (User needs and expectation. Sistem pelaporan dana BOS ini memiliki tiga aktor yaitu admin, bendahara, dan pengawas. Berikut use case diagram yang terdapat dalam sistem pelaporan dana BOS yang ditunjukkan Gambar 2.

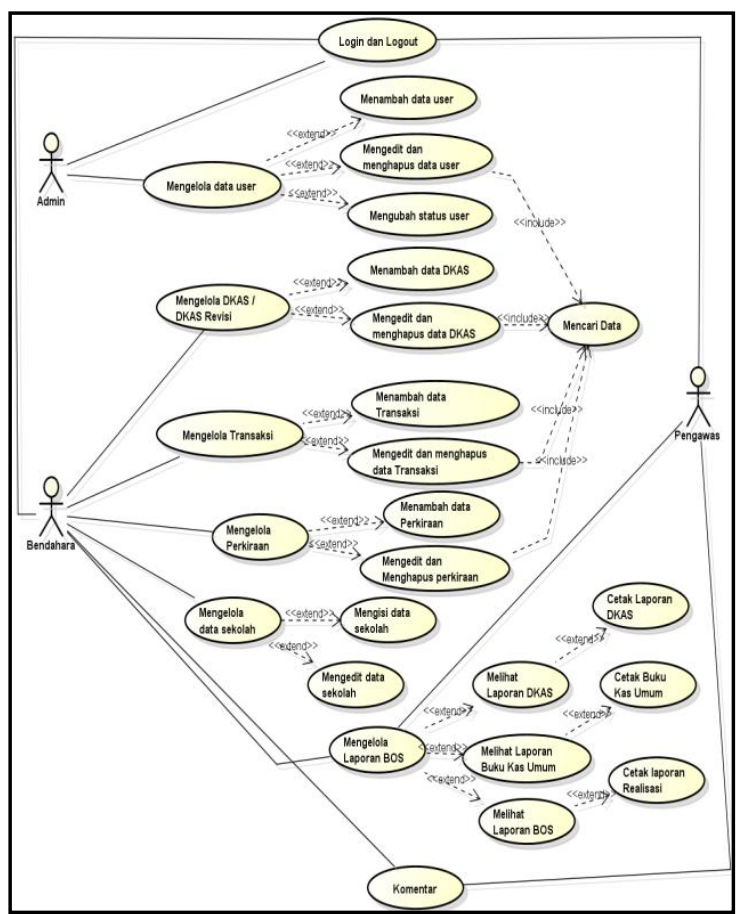

Gambar 2. Use Case Diagram Pelaporan Dana BOS

Tabel 4. Definisi Use Case Diagram Pelaporan Dana BOS

\begin{tabular}{|c|c|}
\hline Use Case & Deskripsi \\
\hline $\begin{array}{l}\text { Login dan } \\
\text { Logout }\end{array}$ & $\begin{array}{l}\text { Pengaturan } \\
\text { autentifikasi } \\
\text { system }\end{array}$ \\
\hline $\begin{array}{l}\text { Mengelola } \\
\text { data user }\end{array}$ & $\begin{array}{lll}\text { Pengaturan } & \text { terhadap } & \text { user } \\
\text { oleh admin } & & \end{array}$ \\
\hline $\begin{array}{l}\text { Mengelola } \\
\text { data } \\
\text { Sekolah }\end{array}$ & $\begin{array}{llr}\text { Pengaturan } & \text { terhadap } & \text { data } \\
\text { sekolah } & \text { yang } & \text { akan } \\
\text { dimasukkan } & & \text { dalam } \\
\text { pembuatan laporan dana } \\
\text { BOS oleh bendahara } \\
\text { sekolah. }\end{array}$ \\
\hline $\begin{array}{l}\text { Mengelola } \\
\text { Perkiraan }\end{array}$ & $\begin{array}{l}\text { Pengaturan terhadap } \\
\text { perkiraan yang akan menjadi } \\
\text { dasar dalam pembuatan } \\
\text { DKAS, yang dilakukan oleh } \\
\text { bendahara sekolah. }\end{array}$ \\
\hline $\begin{array}{l}\text { Mengelola } \\
\text { DKAS / } \\
\text { DKAS }\end{array}$ & $\begin{array}{llr}\text { Pengaturan } & \text { terhadap } \\
\text { pembuatan } & \text { DKAS } & \text { ataupun } \\
\text { DKAS } & \text { Revisi } & \text { oleh }\end{array}$ \\
\hline
\end{tabular}




\begin{tabular}{|l|l|}
\hline Revisi & bendahara sekolah. \\
\hline $\begin{array}{l}\text { Mengelola } \\
\text { Transaksi }\end{array}$ & $\begin{array}{l}\text { Pengolahan terhadap } \\
\text { transaksi oleh bendahara } \\
\text { sekolah. }\end{array}$ \\
\hline $\begin{array}{l}\text { Mengelola } \\
\text { laporan } \\
\text { BOS }\end{array}$ & $\begin{array}{l}\text { Pengolahan terhadap laporan } \\
\text { dana BOS, yang meliputi } \\
\text { laporan DKAS, laporan } \\
\text { Buku Kas Umum dan juga } \\
\text { laporan realisasi anggaran } \\
\text { dana BOS selama triwulan } \\
\text { oleh bendahara sekolah. }\end{array}$ \\
\hline
\end{tabular}

\section{5) Tabel Database Sistem Pelaporan} Dana BOS

Berikut adalah table-tabel yang terdapat dalam database Sistem Pelaporan Dana BOS :

- Tabel user

- Tabel user type

- Tabel DKAS

- Tabel DKAS revisi

- Tabel DKAS revisi 2

- Tabel bendahara

- Tabel kepala sekolah

- Tabel komite sekolah

- Tabel kepala dinas

- Tabel komentar

- Tabel sekolah

- Tabel perkiraan

- Tabel dana bos

- Tabel delapan standart

- Tabel item delapan standart

- Tabel transaksi

- Tabel setting

\section{6) Halaman Website Pelaporan Dana BOS}

Implementasi antarmuka dilakukan dengan setiap halaman web yang dibuat. Implementasi antarmuka yang dibuat adalah sebagai berikut:

- Antarmuka halaman login admin

Halaman ini digunakan admin untuk masuk ke dalam halaman utama admin. Pada halaman ini user diminta memasukkan username dan password.

- Antarmuka halaman user type Halaman ini digunakan admin untuk mengelola level user, diantaranya terdapat level admin, bendahara dan pengawas.

- A7y6ntarmuka halaman user

Halaman ini digunakan admin untuk mengelola user-user yang aktif dalam sistem.

- Antarmuka halaman login bendahara

Halaman ini digunakan bendahara untuk masuk ke dalam halaman utama bendahara.

- Antarmuka halaman setting

Halaman ini digunakan bendahara untuk mengisi data-data sekolah sesuai dengan identitas sekolah. Pada halaman ini diantaranya terdapat data sekolah, kepala sekolah, bendahara, komite sekolah dan sebagainya.

- Antarmuka halaman item delapan standar.

Halaman ini digunakan bendahara untuk mengelola data item delapan standart sesuai dengan kebutuhan pelaporan dana BOS. 
- Antarmuka halaman perkiraan Halaman ini digunakan bendahara untuk mengelola data perkiraan sesuai dengan kebutuhan pelaporan dana BOS.

- Antarmuka halaman DKAS

Halaman ini digunakan bendahara untuk mengelola data DKAS sesuai dengan kebutuhan pelaporan dana BOS.

- Antarmuka halaman DKAS Revisi

Halaman ini digunakan bendahara untuk mengelola data DKAS Revisi sesuai dengan kebutuhan pelaporan dana BOS. DKAS Revisi ini merupakan halaman yang digunakan ketika ada kesalahan pada DKAS sebelumnya.

- Antarmuka halaman Transaksi

Halaman ini digunakan bendahara untuk mengelola data transaksi sesuai dengan kebutuhan pelaporan dana BOS. Halaman transaksi ini mencatat semua penggunaan dana BOS.

- Antarmuka halaman laporan DKAS Halaman ini digunakan bendahara untuk melihat hasil laporan DKAS yang berasal dari data DKAS yang sebelumnya telah dibuat. Pada laporan ini bisa kita export dalam file $p d f$, sehingga lebih mudah untuk dicetak.

- Antarmuka halaman laporan DKAS Revisi

Halaman ini digunakan bendahara untuk melihat hasil laporan DKAS Revisi yang berasal dari data DKAS yang sebelumnya telah dibuat.

- Antarmuka halaman laporan Buku Kas Umum.
Halaman ini digunakan bendahara untuk melihat hasil laporan BKU yang berasal dari data transaksi yang sebelumnya telah dibuat. Pada laporan ini bisa kita export dalam file $p d f$, sehingga lebih mudah untuk dicetak.

- Antarmuka halaman laporan BOS.K-7.

Halaman ini digunakan bendahara untuk melihat hasil laporan BOS-K7 yang berasal dari data DKAS dan transaksi yang sebelumnya telah dibuat.

- Antarmuka halaman laporan BOS K-7a

Halaman ini digunakan bendahara untuk melihat hasil laporan BOS K7 yang berasal dari data DKAS dan transaksi yang sebelumnya telah dibuat. Pada laporan ini bisa kita export dalam file $p d f$, sehingga lebih mudah untuk dicetak.

- Antarmuka halaman login pengawas Halaman ini digunakan pengawas untuk masuk ke dalam halaman utama pengawas.

- Antarmuka halaman komentar

Halaman ini digunakan pengawas untuk berkomunikasi dengan bendahara, pengawas bisa memberikan komentar atas laporan yang telah dibuat oleh bendahara.

\section{Kesimpulan}

Dari uraian pembahasan sistem maka dapat disimpulkan sebagai berikut :

1) Sistem Pelaporan dana BOS ini dibangun berbasis web dengan menggunakan bahasa pemrogaman PHP. Pengguna dalam sistem ini dibagi 
mejadi tiga pengguna pertama admin berfungsi sebagai pengelola user, kedua bendahara berfungsi sebagai pengelola pelaporan dana BOS, dan ketiga pengawas berfungsi sebagai pihak yang mengawasi dan memonitoring pelaporan dana BOS dari tiap-tiap sekolah.

2) Sistem Pelaporan dana BOS dibangun dengan menggunakan database MySQL sebagai penyimpanan datanya. Dalam merancang database tersebut pertama dibuat CDM (Conceptual Data model) terlebih dahulu, kemudian dari CDM di-generate dalam bentuk PDM (Physical Data model), selanjutnya PDM tersebut dirubah dalam bentuk sql yang nantinya File database yang telah berformat sql tersebut digunakan sebagai database sistem pelaporan dana BOS.

3) Sistem Pelaporan dana BOS ini dibangun menggunakan Framework Codeigniter, karena dengan menggunakan framework ini dapat langsung fokus kepada business process yang dihadapi.

\section{Daftar Pustaka}

Arbi. 2004. Management Database dengan MySQL. Yogyakarta: C.V. Andi Offset.

Fowler, Martin. 2005. UML Destilled 3th Ed. Panduan Singkat Bahasa Pemodelan Objek Standar. Yogyakarta: Andi Offset.

Jogiyanto HM. 2009. Sistem Teknologi Informasi. Yogyakarta: C.V. Andi Offset.
Kemdikbud. 2012. Juknis BOS. http://bos.kemdikbud.go.id/media/s hare/upload /files/JUKNIS\%20BOS\% 202013.pdf\%20final.pdf (diakses jam 09.20 tanggal 17 september 2013)

Kemdikbud.2012. Tentang BOS. http://bos.kemdikbud.go.id/home/a bout/ (diakses jam 19:30 tanggal 16 september 2013)

Menkokesra. 2012. Undang-undang Nomor 20 Tahun 2003. http://menkokesra. go.id/node/337 (diakses jam 11.20 tanggal 8 Februari 2014)

Madcoms. 2005. Divisi Penelitian dan Pengembangan Madcoms. Yogyakarta: C.V. Andi Offset.

Palcomtech. 2013. Metode Dan Tahapan Pengembangan Perangkat Lunak. http://news.palcomtech.com/2013/0 5/metode-dan-tahapanpengembangan-perangkat-lunak/ (diakses jam 10.00 tanggal 20 september 2013)

Puspitosari, Heni. 2011. Pemrogaman Web Database dengan PHP dan MySQL. Yogyakarta: Skripta Media Creative.

Sidik, Betha. 2012. Framework

Codeigniter. Bandung: Informatika.

Simarmata, Janner. 2005. Basis Data. Yogyakarta: C.V. Andi Offset. 
Sybase. (2007, April). Conceptual Data Model. USA.

Unigama. 2013. Framework PHP untuk

Pemrogaman Web. http://lpkunigama. com/berita-204-

framework-php-untuk-

pemrograman-web.html (diakses

jam 11.00 tanggal 8 Februari 2014)

Winarko, Edi. 2006. Perancangan

Database dengan Power Designer

6.32. Surabaya: Prestasi Pustaka. 